\title{
GAMBARAN TINGKAT PENGETAHUAN IBU HAMIL TRIMESTER III TENTANG TANDA BAHAYA PERSALINAN
}

\author{
The Overview Level Of Knowledge Of Pregnant Women In Third Trimester About Labor \\ Hazard Signs
}

\author{
${ }^{1}$ Pande Putu Indah Purnamayanthi, ${ }^{2}$ Ni Gusti Ayu Pramita Aswitami, ${ }^{3}$ Ni Putu Ayu Mita Diantari \\ ${ }^{1-3}$ Program Studi Kebidanan, STIKES Bina Usada Bali, Badung, Bali, Indonesia \\ Korespondensi : pandeindah25@gmail.com
}

\begin{abstract}
ABSTRAK
Pengetahuan adalah merupakan hasil tahu dan ini terjadi setelah orang mengadakan penginderaan terhadap suatu objek tertentu. Penginderaan terhadap objek terjadi melalui panca indra manusia yakni penglihatan, pendengaran, penciuman, rasa dan raba dengan sendiri. Sebagian besar pengetahuan manusia diperoleh melalui mata dan telinga. Tujuan penelitian ini adalah untuk mengetahui gambaran tingkat pengetahuan ibu hamil trimester III tentang tanda bahaya persalinan di Wilayah Kerja Puskesmas II Negara. Jenis penelitian ini adalah deskriptif dengan pendekatan secara cross sectional. Sampel dari penelitian ini sebanyak 47 responden dengan menggunakan teknik simple random sampling dengan subjek ibu hamil trimester III. Hasil penelitian ini diperoleh bahwa dari kelima variabel yaitu umur, paritas, pendidikan, pekerjaan, dan sosial ekonomi, variabel yang dominan mempengaruhi pengetahuan yaitu pedidikan. Hasil penelitian Sebagian besar responden dengan tingkat pengetahuan baik diantaranya dari kelompok umur $>35$ tahun sebanyak 5 responden $(62,5 \%)$, paritas grandemultipara sebanyak 4 responden $(12,5 \%)$, pendidikan SMA sebanyak 5 responden $(62,5 \%)$, tingkat pekerjaan swasta sebanyak 4 responden $(50,0 \%)$, dan tingkat sosial ekonomi tinggi sebanyak 5 responden $(62,5 \%)$. Dan variabel pendidikan tujuh kali lebih besar mempengaruhi tingkat pengetahuan. Semoga hasil penelitian ini dapat meningkatkan pengetahuan tentang tanda bahaya persalinan sehingga resiko yang terjadi dapat dicegah dan dapat menurunkan AKI dan AKB.
\end{abstract}

Kata Kunci : ibu hamil trimester tiga, pengetahuan, tanda bahaya persalinan

\section{ABSTRACT}

Knowledge is the result of knowing and it happens after people have sensed a particular object. Sensing of objects occurs through the five human senses, namely vision, hearing, smell, taste and touch. Most human knowledge is obtained through the eyes and ears. The purpose of this study was to describe knowledge level of the third trimester pregnant women about labor hazard signs in the Working Area II Public Health Centre 2018. This type of study was descriptive with cross sectional approach. Number of sample in this study was 47 respondents using simple random sampling technique with the subject of third trimester pregnant women. The results of this study found that out of five variables including age, parity, education, employment, and socio-economic, the dominant variable influences knowledge was education. The results of the study showed that most respondents with good knowledge level including those with aged $>35$ years old was 5 respondents (62.5\%), grande multipara parity was 4 respondents (12.5\%), high school education was 5 respondents $(62.5 \%)$, the level of private employment was 4 respondents (50.0\%), and high socio economical level was 5 respondents $(62.5 \%)$. Education variable seven times greater affected the level of knowledge. Hopefully the results of this study can increase knowledge about labor hazard signals therefore risks that occur can be prevented and can reduce MMR and IMR.

Keywords: third trimester pregnant women, knowledge, labor hazard signals 
Pande Putu Indah Purnamayanthi, dkk: Gambaran Tingkat Pengetahuan Ibu Hamil Trimester III

Tentang Tanda Bahaya Persalinan

\section{PENDAHULUAN}

Kematian dan kesakitan ibu masih merupakan masalah kesehatan serius di negara berkembang. Menurut laporan WHO (2014) Angka Kematian Ibu (AKI) di dunia yaitu 289.000 jiwa. Beberapa negara memiliki AKI cukup tinggi seperti di Afrika Sub Saharan 179.000 jiwa, Asia Selatan 69.000 jiwa, dan Asia Tenggara 16.000 jiwa. Angka kematian ibu di negaranegara Asia Tenggara yaitu Indonesia mencapai 190 per 100.000 kelahiran hidup, Vietnam 49 per 100.000 kelahiran hidup, Thailand 26 per 100.000 kelahiran hidup, Brunei 27 per 100.000 kelahiran hidup, dan Malaysia 29 per 100.000 kelahiran hidup (WHO, 2014).

AKI di Provinsi Bali pada tahun 2011 sebesar mencapai 79,5/100.000 kelahiran hidup, tahun 2012 sebesar 89,6/100.000 kelahiran hidup, tahun 2013 sebesar 72,1/100.000 kelahiran hidup, tahun 2014 sebesar 70,5/100.000 kelahiran hidup, tahun 2015 sebesar 83,4/100.000 kelahiran hidup. Dari data di atas terlihat bahwa AKI di provinsi Bali dari tahun 2011 sampai dengan 2015 sudah mencapai target MDG's 2015 yaitu kurang dari 102/100.000 kelahiran hidup. Namun demikian, trendnya sangat fluktuatif yakni masih mengalami naik turun sehingga diharapkan target AKI di Provinsi Bali dapat menurun setiap tahunnya (Dinkes Provinsi Bali, 2015).

AKI di kabupaten Jembrana menunjukan trend penurunan di tahun 2014 menjadi 42,8/100.000 kelahiran hidup dimana jumlah kematian ibu bersalin sebesar dua orang dari jumlah kelahiran hidup sebesar 4.671 orang dimana tidak ada kematian yang disebabkan dengan diagnose obstetrik dan non obstertik dua orang dan tahun 2015 sebesar 145,7/100.000 kelahiran hidup dimana jumlah kematian ibu bersalin sebesar tujuh orang dari jumlah kelahiran hidup sebesar 4.808 orang terjadi peningkatan dari tahun sebelumnya ini disebkan oleh kematian dengan diagnose obstetrik tiga orang dan non obstetrik empat orang, tahun 2016 sebesar 104,5 / 100.000 kelahiran hidup terjadi penurunan kembali dimana jumlah kematian ibu sebesar lima orang dari jumlah kelahiran hidup sebesar 4.784 orang, ini disebabkan kematian dengan diagnosa obstetrik satu orang, non obstetrik empat orang dan tahun 2017 jumlahnya tetap sama (Dinkes Kabupaten Jembrana, 2017).

Beberapa wanita di Indonesia selalu mempunyai perasaan cemas saat akan melahirkan karena proses persalinan tidak selamanya lancar, tetapi ada beberapa hal yang dapat membahayakan kesehatan ibu dan janinnya. Ada beberapa tanda bahaya kelahiran seperti bayi tidak lahir dalam 12 jam sejak mules (persalinan lama), tali pusat/ekstremitas janin menumbung, kejang dan tidak kuat mengejan, air ketuban keruh dan berbau, retensio plasenta, rasa cemas dan sakit yang hebat. Jika salah satu tanda bahaya tersebut terjadi, akan membahayakan kondisi ibu dan janin sampai menyebabkan kematian (Prawirohardjo, 2013b)

Ibu hamil trimester III sangat penting untuk mengetahui tanda bahaya persalinan karena mereka sudah akan mendekati masa persalinan sehingga, nantinya apabila ibu memiliki pengetahuan yang lebih tentang tanda bahaya persalinan maka kemungkinan besar ibu akan berpikir untuk menentukan sikap, berperilaku untuk mencegah, menghindari atau mengatasi resiko dalam persalinannya nanti dan komplikasi-komplikasi yang mungkin akan terjadi berkurang.

Dilihat dari data AKI Kabupaten Jembrana jumlah kematian ibu bersalin hanya terjadi di Puskesmas II Negara. Selain hal tersebut Berdasarkan studi pendahuluan yang dilakukan pada tanggal 19-23 bulan Maret 2018 di ruang KIA Puskesmas II Negara terdapat sepuluh ibu hamil trimester III untuk melakukan kunjungan ulang. Dan pada saat dilakukan pengisian kuesioner terdapat $70 \%$ dari $100 \%$ ibu hamil trimester III tersebut kurang mengetahui tentang tanda bahaya persalinan. Berdasarkan uraian diatas, maka hal tersebut mendorong penulis untuk melakukan penelitian tentang gambaran tingkat pengetahuan ibu hamil trimester iii tentang tanda bahaya persalinan di Wilayah Kerja Puskesmas II Negara. 
Pande Putu Indah Purnamayanthi, dkk: Gambaran Tingkat Pengetahuan Ibu Hamil Trimester III

Tentang Tanda Bahaya Persalinan

\section{TUJUAN PENELITIAN}

Tujuan dalam penelitian ini adalah untuk mengidentifikasi tingkat pengetahuan ibu hamil trimester III di wilayah kerja Puskesmas II Negara.

\section{METODE PENELITIAN}

Desain

Jenis penelitian yang digunakan pada penelitian ini adalah deskriptif observasional. Pendekatan yang digunakan terhadap subyek penelitian adalah memakai pendekatan cross sectional (Arikunto, 2007).

\section{Populasi dan Sampel}

Populasi dalam penelitian ini adalah 73 ibu hamil. Besar sanpel dalam penelitian ini sebanyak 47 orang, yang memenuhi kriteria inklusi dan eksklusi penelitian dengan Teknik purposive sampling Adapun proses atau langkah-langkah yang dilakukan dalam pengambilan sampel yaitu yang pertama menulis daftar nama populasi atau sampel frame sebanyak 73 orang kemudian mengidentifikasi populasi dengan melakukan kunjungan pada populasi tersebut dan didapatkan ada enam belas ibu hamil trimester III yang sakit dan sepuluh ibu hamil trimester III yang pindah. Sehingga didapatkan jumlah sampel dalam penelitian ini adalah 47 orang ibu hamil trimester III.

\section{Tempat dan Waktu Penelitian}

Penelitian ini dilakukan sejak Bulan Maret 2018. Lokasi penelitian yaitu di Puskesmas II Negara.

\section{Instrumen dan Prosedur Pengukuran}

Instrumen yang digunakan dalam penelitian ini adalah kuisioner yang disusun tersetruktur untuk menggambarkan pengetahuan ibu hamil trimester III tentang tanda bahaya persalinan dengan daftar pertanyaan (kuisioner). Analisa pengumpulan data yang digunakan adalah kuisioner tertutup. Cara pengisian adalah dengan member tanda centang $(\sqrt{ })$ pada jawaban yang responden anggap benar. Peneliti mengajukan 10 pertanyaan untuk responden untuk dijawab. Bila responden mampu menjawab dengan benar 76\% -
$100 \%$ maka tingkat pengetahuan baik, 56\% - 75\% tingkat pengetahuan cukup, kurang dari $56 \%$ tingkat pengetahuan dianggap kurang.

Hasil uji validitas kuisioner didapatkan hasil bahwa kuisioner pengetahuan yang berisi 10 pertanyaan didapatkan hasiluji menunjukkan bahwa nilai $\mathrm{r}$ hitung tertinggi 0,985 dan $\mathrm{r}$ hitung terendah 0,668 dengan menggunakan tingkat kemaknaan 0,05 diperoleh dari $r$ tabel 0,632, maka $r$ hitung $>r$ tabel dan kuesioner dinyatakan valid. Sedangkan uji reabilitas kuisioner didapatkan hasil uji menunjukan bahwa nilai $r$ hasil 0,739 sedangkan nilai konstanta sebesar 0,361 sehingga konstanta $<\mathrm{r}$ hasil $\mathrm{r}$ instrument dinyatakan reliabel.

\section{Analisa Data}

Analisa data menggunakan uji univariat untuk melihat distribusi tingkat pengetahuan ibu.

\section{HASIL PENELITIAN} berikut:

Hasil penelitian dirangkum sebagai

Tabel 1.

Karakteristik Responden $(\mathrm{n}=47)$

\begin{tabular}{lll}
\hline \multicolumn{1}{c}{ Variabel } & \multicolumn{1}{c}{ f } & \multicolumn{1}{c}{$\%$} \\
\hline Usia & & \\
$<20$ tahun & 12 & 25,54 \\
$20-35$ tahun & 22 & 46,80 \\
$>35$ tahun & 13 & 27,66 \\
Paritas & & \\
$\quad$ Nulipara & 0 & 0 \\
Primipara & 10 & 21,28 \\
Multipara & 23 & 48,94 \\
Grandemultipara & 14 & 29,78 \\
Pendidikan & & \\
SD & 11 & 23,40 \\
SMP & 9 & 19,15 \\
SMA & 27 & 57,45 \\
Perguruan tinggi & 0 & 0 \\
Jenis Pekerjaan & & \\
Ibu Rumah Tangga & 21 & 44,68 \\
Petani / Buruh & 18 & 38,30 \\
Wiraswasta & 0 & 0 \\
PNS & 0 & 0 \\
Swasta & 8 & 17,02 \\
Sosial Ekonomi & & \\
Tinggi & 5 & 10,64 \\
Sedang & 18 & 38,30 \\
Rendah & 24 & 51,06 \\
\hline
\end{tabular}


Pande Putu Indah Purnamayanthi, dkk: Gambaran Tingkat Pengetahuan Ibu Hamil Trimester III

Tentang Tanda Bahaya Persalinan

Berdasarkan tabel diatas, dari 47 responden diperoleh hasil sebagian besar responden dengan umur $20-35$ tahun sebanyak 22 responden $(46,80 \%)$. Sebagian besar responden dengan paritas multipara sebanyak 23 responden (48,94\%). Dari 47 responden diperoleh hasil sebagian besar responden dengan tingkat pendidikan SMA yaitu sebanyak 27 responden $(57,45 \%)$. Sebagian besar responden dengan jenis pekerjaan sebagai Ibu Rumah Tangga yaitu sebanyak 21 responden (44,68\%). Sebagian besar responden dengan tingkat penghasilan rendah yaitu sebanyak 24 responden $(51,06 \%)$.

Tabel 2.

Tingkat Pengetahuan Ibu $(\mathrm{n}=47)$

\begin{tabular}{|c|c|c|}
\hline $\begin{array}{c}\text { Tingkat } \\
\text { Pengetahuan }\end{array}$ & $\mathrm{f}$ & $\%$ \\
\hline Baik & 8 & 17,02 \\
\hline Cukup & 23 & 48,94 \\
\hline Kurang & 16 & 34,04 \\
\hline Jumlah & 47 & 100 \\
\hline
\end{tabular}

Berdasarkan tabel diatas, dapat dilihat bahwa dari 47 responden diperoleh hasil sebagian besar responden memiliki tingkat pengetahuan yang cukup sebanyak 23 responden $(48,94 \%)$.

\section{PEMBAHASAN}

Karakteristik Responden Berdasarkan Tingkat Pengetahuan Ibu Hamil Trimester III

Tingkat pengetahuan ibu hamil trimester III tentang tanda bahaya persalinan berdasarkan tingkat umur di Wilayah Kerja Puskesmas II Negara dengan tingkat pengetahuan baik pada umur $>35$ tahun sebanyak (62,5\%), sedangkan jumlah tingkat pengetahuan cukup terbanyak pada umur $20 \quad-35$ tahun yaitu $(73,9 \%)$, dan tingkat pengetahuan kurang terbanyak pada umur $<20$ tahun yaitu $(50,0 \%)$. Umur merupakan salah satu faktor yang sangat berpengaruh terhadap tingkat pengetahuan seseorang. Umur mempengaruhi daya tanggap dan pola fikir seseorang. Semakin bertambahnya umur maka akan semakin berkembang pula daya tangkap dan fola fikirnya, sehingga pengetahuan yang diperoleh semakin baik,serta semakin banyak informasi yang di jumpai maka semakin banyak hal yang dikerjakan sehingga menambah pengetahuannya (Notoatmodjo, 2010).

Paritas mempengaruhi tingkat pengalaman seseorang terhadap persalinan, nifas, bayi dan menyusui. Semakin banyak paritas maka makin banyak pengalaman yang dimiliki oleh ibu. Orang akan banyak belajar dari pengalaman - pengalaman yang sudah dialami sebelumnya termasuk tentang persalinan (Prawirohardjo. S, 2013a). Semakin tinggi tingkat pendidikan seseorang maka semakin mudah orang tersebut untuk menerima informasi sehingga semakin luas juga pengetahuan yang didapat. Dengan pendidikan tinggi maka seseorang akan cendrung untuk mendapatkan informasi baik dari orang lain maupun dari media massa. Sebaliknya, tingkat pendidikan yang kurang akan menghambat perkembangan dan sikap seseorang terhadap nilai-nilai yang baru diperkenalkan (Notoatmodjo, 2010). Status ekonomi seseorang juga akan menentukan tersedianya fasilitas yang diperlukan untuk kegiatan tertentu. Status ekonomi adalah kedudukan seseorang atau keluarga di masyarakat berdasarkan pendapatan per bulan (Notoatmodjo, 2010).

\section{Tingkat Pengetahuan Ibu Hamil Trimester} III Tentang Tanda Bahaya Persalinan

Berdasarkan hasil penelitian yang dilakukan di Wilayah Kerja Puskesmas II Negara dapat dilihat bahwa dari 47 responden diperoleh hasil yaitu sebagian besar responden memiliki tingkat pengetahuan cukup yaitu sebanyak $(48,94 \%)$. Hasil penelitian ini menunjukkan bahwa tingkat pengetahuan ibu hamil trimester III sebagian besar dengan kategori cukup. Ibu hamil trimester III dengan kategori pengetahuan cukup akan mudah dalam menerima informasi tentang tanda bahaya persalinan. Hal ini juga didukung oleh teori menurut Sukarni (2013), dimana pengetahuan adalah hasil dari tahu dan ini terjadi setelah orang melakukan pengindraan terhadap suatu obyek. Pengetahuan diperoleh dari proses belajar, proses belajar dapat terjadi dimana saja dan kapan saja. Tinggi rendahnya pengetahuan 
Pande Putu Indah Purnamayanthi, dkk: Gambaran Tingkat Pengetahuan Ibu Hamil Trimester III Tentang Tanda Bahaya Persalinan

seseorang diperoleh oleh umur, pendidikan, dan pengalaman. Hal tersebut dapat menjadi dasar kenapa tingkat pengetahuan ibu hamil trimester III tentang tanda bahaya persalinan cukup.

\section{KESIMPULAN}

Implikasi

Bagi seorang ibu hamil trimester III perlu memiliki pengetahuan yang baik tentang tanda bahaya persalinan untuk mengurangi kecemasan menjelang persalinan. Dengan peningkatan pengetahuan ibu diharapkan ibu hamil dan keluarga dapat menambah informasi dan wawasan betapa pentingnya pengetahuan tanda bahaya persalinan.

\section{Keterbatasan}

Pada penggunaan materi instrumen dimana penggunaan bahasa dan istilah medis yang sulit dipahami oleh responden dapat mempengaruhi jawaban dari responden. Sehingga diperlukan penggunaan istilah-istilah yang dapat memudahkan pemahaman responden.

\section{DAFTAR PUSTAKA}

Arikunto, S. (2007). Prosedur Penelitian Suatu Pendekatan Praktek. Rineka Cipta.

Dinkes Kabupaten Jembrana. (2017). Profil Dinas Kesehatan Kabupaten Jembrana, Jembrana.

Dinkes Provinsi Bali. (2015). Profil Kesehatan Dinas Kesehatan Provinsi Bali.

Notoatmodjo, S. (2010). Metodologi Penelitian Kesehatan. Rineka Cipta.

Prawirohardjo, S. (2013a). Ilmu Kebidanan. PT Bina Pustaka.

Prawirohardjo. S. (2013b). Pelayanan Kesehatan Maternal dan Neonatal. PT Bina Pustaka.

Sukarni, D. M. (2013). Kehamilan, Persalinan, dan Nifas. Nuha Medika.

WHO. (2014). World Health Statistic. http://www.who.int 